\title{
Dehydrobufotenin extracted from the Amazonian toad Rhinella marina (Anura: Bufonidae) as a prototype molecule for the development of antiplasmodial drugs
}

Felipe Finger Banfi', Gabriela Camila Krombauer ${ }^{1}$, Amanda Luisa da Fonseca ${ }^{2}$ (D), Renata Rachide Nunes², Silmara Nunes Andrade², Millena Alves de Rezende², Mariana Helena Chaves ${ }^{3}$, Evaldo dos Santos Monção Filho ${ }^{3}$, Alex Guterres Taranto², Domingos de Jesus Rodrigues ${ }^{4}$, Gerardo Magela Vieira Júnior ${ }^{3}$ (D), Whocely Victor de Castro ${ }^{5}$, Fernando de Pilla Varotti²*, Bruno Antonio Marinho Sanchez ${ }^{1 *}$ (D)

'Laboratory of Immunopathology and Tropical Diseases, Health Education and Research Center (NUPADS), Institute of Health Sciences, Federal University of Mato Grosso, Sinop, MT, Brazil.

${ }^{2}$ Research Center on Biological Chemistry (NQBio), Federal University of São João Del Rei, Divinópolis, MG, Brazil.

${ }^{3}$ Department of Chemistry, Federal University of Piauí, Teresina, PI, Brazil.

${ }^{4}$ Center for Biodiversity Studies in the Amazon Region of Mato Grosso (NEBAM), Federal University of Mato Grosso, MT, Brazil.

${ }^{5}$ Quality Control Laboratory, Federal University of São João Del Rei, Divinópolis, MG, Brazil.

\section{Keywords:}

Bufadienolides

Antimalarial drug

Docking

Natural compounds

\begin{abstract}
Background: The resistance against antimalarial drugs represents a global challenge in the fight and control of malaria. The Brazilian biodiversity can be an important tool for research and development of new medicinal products. In this context, toxinology is a multidisciplinary approach on the development of new drugs, including the isolation, purification, and evaluation of the pharmacological activities of natural toxins. The present study aimed to evaluate the cytotoxicity, as well as the antimalarial activity in silico and in vitro of four compounds isolated from Rhinella marina venom as potential oral drug prototypes. Methods: Four compounds were challenged against 35 target proteins from P. falciparum and screened to evaluate their physicochemical properties using docking assay in Brazilian Malaria Molecular Targets (BraMMT) software and in silico assay in OCTOPUS ${ }^{\circ}$ software. The in vitro antimalarial activity of the compounds against the 3D7 Plasmodium falciparum clones were assessed using the SYBR Green I based assay $\left(\mathrm{IC}_{50}\right)$. For the cytotoxic tests, the $\mathrm{LD}_{50}$ was determined in human pulmonary fibroblast cell line using the [3(4,5-dimethylthiazol2-yl)-2,5-diphenyltetrazolium bromide] (MTT) assay.

Results: All compounds presented a ligand-receptor interaction with ten Plasmodium falciparum-related protein targets, as well as antimalarial activity against chloroquine resistant strain $\left(\mathrm{IC}_{50}=3.44 \mu \mathrm{M}\right.$ to $19.11 \mu \mathrm{M}$ ). Three of them (dehydrobufotenine, marinobufagin, and bufalin) showed adequate conditions for oral drug prototypes, with satisfactory prediction of absorption, permeability, and absence of toxicity. In the cell viability assay, only dehydrobufotenin was selective for the parasite.

Conclusions: Dehydrobufotenin revealed to be a potential oral drug prototype presenting adequate antimalarial activity and absence of cytotoxicity, therefore should be subjected to further studies.
\end{abstract}

* Correspondence: bamsanchez@hotmail.com and varotti@ufsj.edu.br https://doi.org/10.1590/1678-9199-JVATITD-2020-0073

Received: 07 May 2020; Accepted: 28 October 2020; Published online: 08 January 2021

On-line ISSN 1678-9199 (c) The Author(s). 2021 Open Access This article is distributed under the terms of the Creative Commons Attribution 4.0 International License (http:// creativecommons.org/licenses/by/4.0/), which permits unrestricted use, distribution, and reproduction in any medium, provided you give appropriate credit to the original author(s) and the source, provide a link to the Creative Commons license, and indicate if changes were made. The Creative Commons Public Domain Dedication waiver (http://creativecommons.org/ publicdomain/zero/1.0/) applies to the data made available in this article, unless otherwise stated. 


\section{Background}

Malaria is an important human parasitic disease, occurring in tropical and subtropical areas of the planet [1]. The malaria parasites resistance to ancient antimalarials consists of the biggest hurdles to malaria control [2]. Because of the resistance to antimalarials, artemisinin and its derivatives have been the firstline antimalarial agents against Plasmodium falciparum [3,4]. Artemisinin-based combination therapies (ACT) are the most effective regimens for the first-line treatment for $P$. falciparum infections. Despite of the WHO recommendations for using and prescribing the ACTs, pharmacokinetic and pharmacodynamic studies with $P$. falciparum strains have already demonstrated the development of resistance to these compounds [5,6,7]. This phenomenon is responsible to increase the mortality in endemic areas contributing to the appearance and expansion of new outbreaks of $P$. falciparum malaria. Thus, new strategies are required to prevent increased resistance to ACTs. In addition, a potential strategy would be to add a third drug with independent antiparasitic activity [6].

Natural products have providing a great contribution to the development of new drugs [8]. In fact, many of the antimalarial drugs commercially available are derivatives of phytoconstituents [9]. In addition to the plant-derived remedies, animal extracts, products, and even secretions are also a source of a plethora of therapeutical agents [10].

The venoms secreted by the paratoid glands of amphibians from the order Anura is the first line of defense against predators and microorganisms $[11,12]$. The toads of Bufonidae family have been widely studied due to the bioactive properties found in the Rhinella marina venom, which have already shown antitumor $[13,14,15]$, antiviral $[16,17]$, and antiparasitic activities [18]. The cholesterol-derived steroid structures called bufadienolides are major active compounds in the venom of Bufonidae family and are considered a promising source of bioproducts $[19,20]$. Furthermore, the alkaloids dehydrobufotenin and bufotenine also identified in R. marina venom have demonstrated to possess antiproliferative and antiviral activity, respectively [20,21, 22, 23].

The development of malaria drugs is slower than that involving the antibacterial drugs [24]. However, this process can be speeded up with the aid of computational drug planning tools, known as molecular modeling or docking, to design new compounds and to study their respective protein targets $[25,26]$. The docking is a robust tool for investigating the chemical interactions of ligands and receptors and to explore the structural factors related to the biological effect $[27,28]$.

To date, there are almost no studies investigating compounds isolated from the bufonides venom as potential new antimalarial drugs. Therefore, present study aimed to evaluate the cytotoxicity, as well as the antimalarial activity in silico and in vitro of four compounds isolated from Rhinella marina venom as potential oral drug prototypes.

\section{Methods}

\section{Sample collection}

The animals (R. marina) were collected in the Branca de Neve Community, Mato Grosso, Brazil (Latitude 11 ${ }^{\circ} 51^{\prime} 51.59$ “S/ Longitude $55^{\circ} 22^{\prime} 47.99^{\prime \prime}$ W), from January to March of 2015, in the municipality of Sinop, Mato Grosso state, North-Western Brazil. The vegetation where the individuals were found is classified as dense humid forest and the climate of the region is tropical with an average temperature of $24^{\circ} \mathrm{C}$, relative air humidity of $\sim 80 \%$, and average annual rainfall of $2,034 \mathrm{~mm}$.

The amphibians were captured and identified by the biologist (D. J. Rodrigues - 95 IBAMA, SISBIO: number 30034-1). The secretions were obtained by manual compression of the parotoid macrogland and the animals were returned to nature after this procedure. The voucher specimens (R. marina - ABAM-H 2256) were collected and deposited in the zoological collection (Acervo Biológico da Amazônia Meridional) of the Federal University of Mato Grosso located at Sinop city (the collection permit was issued by the Chico Mendes Institute for Biodiversity Conservation).

All experiments were performed according to internationally accepted guidelines for the care and use of laboratory animals and were previously approved by the Federal University of Mato Grosso Institutional Animal Care and Use Committee (Protocol 23108.700260/14-7) and National System for the Management of Genetic Heritage and Associated Traditional Knowledge (SisGen AE 19081).

\section{Extraction of $\boldsymbol{R}$. marina Venom samples and isolation}

$R$. marina toad venoms were dried, powdered and extracted three times $(3 \times 20 \mathrm{~mL})$ with $100 \%$ methanol $(\mathrm{MeOH})$ in ultrasound waves for 10 minutes at room temperature [14]. The extract was fractionated on Sephadex LH-20 column using methanol as eluent. Four fractions were obtained: CRV-6 (783.8 mg); CRV-28 (102.9 $\mathrm{mg}$ ); CRV-52 (315.8 mg) and CRV-70 (394.1 mg). The structure of the isolated compounds marinobufotoxin, dehydrobufotenin, marinobufagin, and bufalin are presented in Figure 1 [29].

\section{Evaluation of molecular docking}

The compounds were designed using MarvinSketch software (ChemAxon, Cambridge, MA, USA) and the molecular structures were refined through MOPAC ${ }^{\circ}$ software (Stewart Computational Chemistry, Colorado Springs, CO, USA) using the PM7 semiempirical method. The compounds dehydrobufotenine, marinobufotoxin, marinobufagin and bufalin were submitted to the molecular docking calculations in the AutoDock Vina program [30] using OCTOPUS ${ }^{\circ}$ platform [31] and the configuration files were determined through a re-docking step [32]. Thus, the virtual screening of antimalarial drugs 


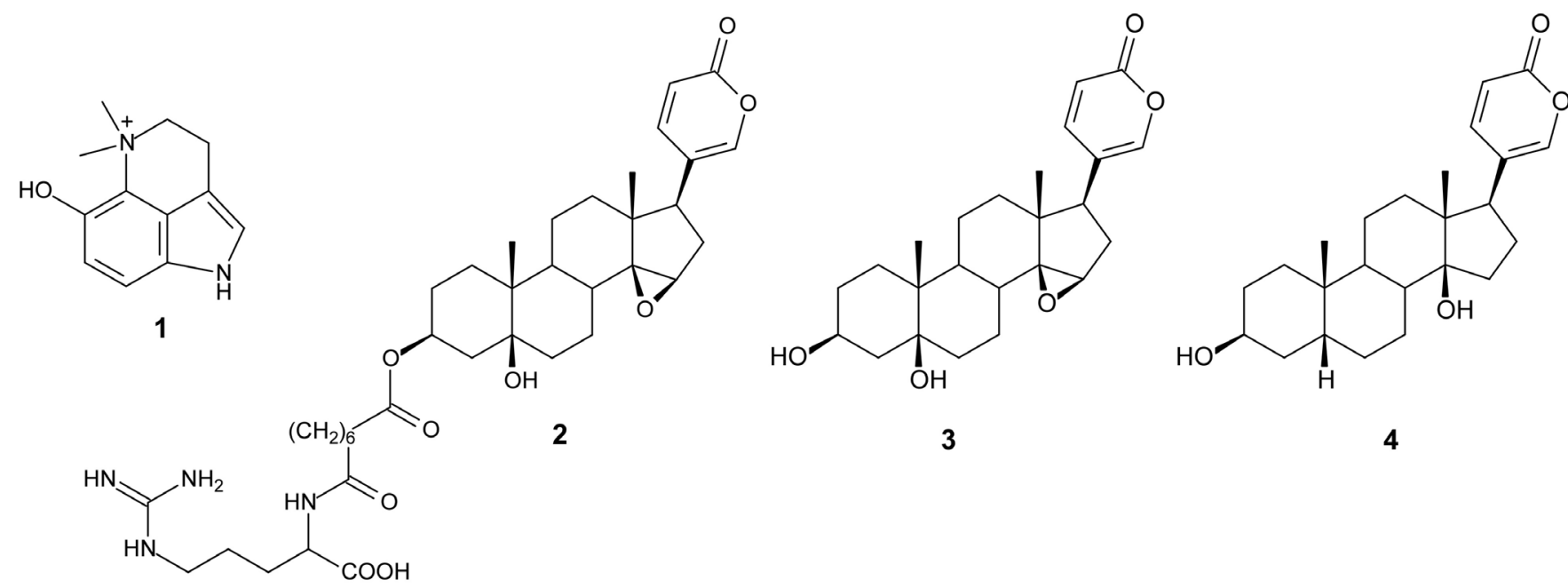

Figure 1. Molecular structures of R. marina venom fractions. (1) Dehydrobufotenine (CRV - 28), (2) marinobufotoxin (CRV-6-21-58), (3) marinobufagin (MB-1) and (4) bufalin (MB-3).

was performed using the BraMMT data bank according [33]. From the generated binding energy values, $\Delta$ (binding energy of the crystallographic ligand - binding energy of the compound) values were calculated. Thus, $\Delta$ values greater than " 0 ", show that it has higher binding energy than the crystallographic ligand, suggesting greater interaction with the target. Table 1 lists the molecular targets used to build the BraMMT platform.

\section{Evaluation of physicochemical and ADMET properties}

The physicochemical and ADMET properties of the compounds dehydrobufotenin, marinobufotoxin, marinobufagin and bufalin (CRV-28, CRV-6-28-51, MB-1 and MB-3, respectively) were analyzed using DataWarrior software and SwissADME website [34]. The properties of molecular mass, partition coefficient (ClogP), number of hydrogen donor groups, and number of hydrogen acceptor groups were predicted. The toxicological characteristics of the ligand, such as mutagenicity, tumogenicity, and irritability, were analyzed [35]. Finally, the pharmacokinetic processes of absorption, distribution, metabolism, excretion, and toxicity were estimated [34].

\section{In vitro culture of $P$. falciparum}

P. falciparum W2 strain (chloroquine resistant) [36, 37, 38] was cultured in blood stage culture to test the antiplasmodial efficacy of toad venom compounds (1, 2, 3, and 4). P. falciparum continuous culture was maintained as previously described $[36,39]$ with minor modifications. Parasites were maintained at 5\% hematocrit using type $\mathrm{O}^{+}$human erythrocytes in RPMI 1640 medium (Sigma-Aldrich', St. Louis, Missouri, USA) supplemented with $25 \mathrm{mM} \mathrm{NaHCO}_{3}, 1.0 \%$ albumax, $45 \mathrm{mg} / \mathrm{L}$ hypoxanthine, 40 $\mu \mathrm{g} / \mathrm{mL}$ gentamycin and incubated at $37^{\circ} \mathrm{C}$ under approximately $5 \%$ of $\mathrm{CO}_{2}$. The parasites at early stages were synchronized at ring stage by sorbitol treatment [40]. Initial parasitemia was adjusted to $0.5 \%$ with $2 \%$ hematocrit in all experiments.

\section{In vitro antiplasmodial activity}

In vitro antiplasmodial activity of the bufadienolides (compounds dehydrobufotenin, marinobufotoxin, marinobufagin and bufalin) was done in 96 well plates [41]. The growth inhibition of intraerythrocytic forms and parasite morphology in culture was assessed by microscopic observation of the Giemsa-stained thin blood films. Ring stage parasites (0.5\% parasitemia and 2\% hematocrit) were added to each well of 96-well microculture plates. The compounds (dehydrobufotenin, marinobufotoxin, marinobufagin and bufalin) were dissolved in DMSO and diluted to concentrations ranging from 0.78 to $100 \mu \mathrm{g} / \mathrm{mL}$ using complete medium and stored a $4^{\circ} \mathrm{C}$. After incubation at $37^{\circ} \mathrm{C}$ for 48 hours, $P$. falciparum growth inhibition was assessed in Giemsa-stained smears by observing 5,000 erythrocytes per 1 thin blood film in triplicate. The culture medium was replaced with fresh medium with or without test samples/control drugs. Chloroquine (CQ) was used as a reference antimalarial. The activity of the compounds (dehydrobufotenin, marinobufotoxin, marinobufagin and bufalin) was expressed as the percentage reduction in parasitemia relative to controls without drugs. All experiments were performed in triplicate. The results were expressed as the mean of the $\mathrm{IC}_{50}$ (Drug concentration that reduced parasite viability in $50 \%$ ).

\section{In vitro cytotoxicity}

In vitro cytotoxicity of each compound was assessed on WI26VA4 (ATCC CCL-95.1, USA) human pulmonary fibroblast cells. The cells were cultured in RPMI-1640 (Sigma-Aldrich', St. Louis, Missouri, USA) medium supplemented with $10 \%$ heatinactivated fetal bovine serum and $100 \mu \mathrm{g} / \mathrm{mL}$ of gentamycin in a $5 \% \mathrm{CO}_{2}$ atmosphere at $37^{\circ} \mathrm{C}$. The cells were washed with culture 
Table 1. Molecular targets, location and enzymatic class of the 35 molecular targets obtained from the Tropical Disease Research (TDR target database) for building the Brazilian Malaria Molecular Targets (BraMMT).

\begin{tabular}{|c|c|c|c|}
\hline PDB Code & Name & Enzymatic class & Location \\
\hline $1 \mathrm{LF} 3$ & Plasmepsin II & Hydrolase & Digestive vacuole \\
\hline 1NHW & Enoyl-acyl-carrier-protein reductase & Oxidoreductase & Apicoplast \\
\hline 1QNG & Peptidyl-prolil cis-trans isomerase & Isomerase & Cytoplasm \\
\hline 1RL4 & Formylmethionine deformylase & Hydrolase & Apicoplast \\
\hline $1 T V 5$ & Dihydroorotate dehydrogenase & Oxidoreductase & Cytoplasm e Nucleus \\
\hline 2AAW & Glutathione s-transferase & Transferase & Cytoplasm \\
\hline 2ANL & Plasmepsin IV & Hidrolase & Digestive vacuole \\
\hline $20 K 8$ & Putative ferredoxin--NADP reductase & Oxidoreductase & Apicoplast \\
\hline 2PML & Ser/Thr protein kinase & Transferase & Cytoplasm \\
\hline 2Q8Z & Orotidine-monophosphate-descarboxylase & Liase & Nucleus \\
\hline 2VFA & Hypoxantine-guanine phosphoribosyltransferase & Transferase & Apicoplast \\
\hline 2VN1 & $70 \mathrm{KDA}$ peptidylprolyl isomerase & Isomerase & Nucleus \\
\hline 3FNU & HAP Protein & Hydrolase & Digestive vacuole \\
\hline $3 K 7 Y$ & Aspartate aminotransferase & Transferase & Cytoplasm \\
\hline 3N3M & Orotidine 5'-phosphate decarboxylase & Lyase & Apicoplast \\
\hline 3PHC & Purine nucleoside phosphorylase & Transferase & Nucleus \\
\hline 3QS1 & Plasmepsin I & Hydrolase & Digestive vacuole \\
\hline 3T64 & Deoxyuridine 5'-triphosphate nucleotidohydrolase & Hydrolase & Nucleus \\
\hline 3TLX & Adenylate kinase 2 & Transferase & Cytoplasm and mitochondria \\
\hline 4B1B & Thioredoxin reductase & Oxidoreductase & Cytoplasm \\
\hline $4 C 81$ & 22-C-Methyl-D-Erythritol 2,4-Cyclodiphosphate synthase & Lyase & Apicoplast \\
\hline $4 J 56$ & Thioredoxin reductase 2 & Oxidoreductase & Cytoplasm \\
\hline 4NOZ & Glutaredoxin & Oxidoreductase & Cytoplasm \\
\hline 4P7S & Macrophage migration inhibitory factor-like protein & Cytokine inhibitor & Cytoplasm \\
\hline 4QOX & Calcium-dependent protein kinase 4 & Transferase & Cytoplasm \\
\hline PfATP6 & Calcium pump ortholog ATPase & Transporter & Membrane \\
\hline $\begin{array}{l}\text { PfHT } \\
(10.5452 / \text { ma-aej21) }\end{array}$ & Hexose carrier protein & Transporter & Membrane \\
\hline
\end{tabular}


medium, trypsinized, distributed in a flat-bottomed 96-well plate $\left(5 \times 10^{3}\right.$ cells/well), and incubated for 18 hours at $37^{\circ} \mathrm{C}$ for cell adherence [42]. The compounds $(20 \mu \mathrm{L})$ were diluted in different concentrations ranging from $0.2-200 \mu \mathrm{g} / \mathrm{mL}$ and incubated with the cells for 24 hours in a $5 \% \mathrm{CO}_{2}$ atmosphere at $37^{\circ} \mathrm{C}$.

A 3-(4,5-dimethylthiazol-2-yl)-2,5-diphenyltetrazolium bromide (MTT) solution ( $5 \mathrm{mg} / \mathrm{mL} ; 20 \mu \mathrm{L} /$ well) was added to evaluate mitochondrial viability; after a further 3 hours incubation, the supernatants were carefully removed, $100 \mu \mathrm{L}$ of DMSO was added to each well, and the reactions were mixed to solubilize the formazan crystals. The optical density was determined at 540 $\mathrm{nm}$ to measure the signal and background, respectively (Spectra Max340PC ${ }^{384}$, Molecular Devices, Sunnyvale, California, USA) $[43,44,45,46,47,48]$. The cell viability was expressed as a percentage of the control absorbance in the untreated cells after subtracting the appropriate background.

The minimum lethal dose for $50 \%$ of the cells $\left(\mathrm{LD}_{50}\right)$ was determined as described [49].

\section{Selectivity index (SI)}

A selectivity index (SI) corresponding to the ratio between the cytotoxic and antiplasmodial activities of each compound tested. The values greater than 10 were considered indicative of lack of toxicity, whereas the substances with values below 10 were considered toxic [38]. The SI index was calculated as follow:

$$
\mathrm{SI}=\frac{\mathrm{LD}_{50} \text { Cell }}{\mathrm{IC}_{50} P . \text { falciparum }}
$$

\section{Statistical analysis}

The concentrations of compounds able to inhibit $50 \%$ of parasite growth $\left(\mathrm{IC}_{50}\right)$ were determined based on the equation of the curve obtained by plotting the \% of parasitemia regression vs the log of the concentration of compound. The coefficients of regression of these curves were calculated using the method of least squares. The $\mathrm{LD}_{50}$ were determined based on the equation of the curve obtained by plotting the $\%$ of cellular death versus the concentration of compound (GraphPad Prism Software, version 5.0 for Windows, San Diego, California, USA). The average $\mathrm{IC}_{50}$ and $\mathrm{LD}_{50}$ were compared using ANOVA. Statistical significance was defined at the $5 \%$ level $(\mathrm{P}<0.05)$.

\section{Results}

\section{Compounds}

\section{Compound 1 (CRV - 28)}

Dehydrobufotenin - molecular formula: $\mathrm{C}_{15} \mathrm{H}_{12} \mathrm{~N}_{2} \mathrm{O}$; IT-ESIMS $[\mathrm{M}+\mathrm{H}]^{+} 203.1 ;{ }^{1} \mathrm{H}$ NMR (CD $\left.\mathrm{OD}-600 \mathrm{MHz}\right): \delta 7.11(\mathrm{~s}, 1 \mathrm{H})$, $\delta 6.81(\mathrm{~d}, J=8.6 \mathrm{~Hz}, 1 \mathrm{H}), \delta 7.29(\mathrm{~d}, J=8.7 \mathrm{~Hz}, 1 \mathrm{H}), \delta 3.29(\mathrm{~d}, J=$ $5.8 \mathrm{~Hz}, 2 \mathrm{H}), \delta 4.1(\mathrm{t}, J=5.9 \mathrm{~Hz}, 2 \mathrm{H})$ and $\delta 3.68(\mathrm{~s}, 6 \mathrm{H}) .{ }^{13} \mathrm{C} \mathrm{NMR}$ $\left(\mathrm{CD}_{3} \mathrm{OD}-150 \mathrm{MHz}\right): \delta 122.5, \delta 120.6, \delta$ 104.6, $\delta$ 121.1, $\delta$ 149.0, $\delta 115.0, \delta 118.9, \delta 128.9, \delta 20.0, \delta 69.6$ and $\delta 54.0$.
The CRV-6 fraction was submitted to the Sephadex LH-20 column with $\mathrm{MeOH}$. The sub-fractions CRV-6-28 was further fractionated by silica gel column, eluted in $\mathrm{CHCl}_{3} / \mathrm{MeOH}$ with an increasing polarity gradient system. The subgroup obtained was CRV-6-28-51 (35.1 mg) and through NMR analysis and mass spectrometry was identified as marinobufotoxin (2).

\section{Compound 2 (CRV-6-28-51)}

3-(N-suberoylargininyl) marinobufagin (marinobufotoxin) molecular formula: $\mathrm{C}_{38} \mathrm{H}_{56} \mathrm{~N}_{4} \mathrm{O}_{9}$; IT-ESI-MS $[\mathrm{M}+\mathrm{H}]^{+} 713.5 ;{ }^{1} \mathrm{H}$ NMR (CD $\left.\mathrm{OD}_{3} 600 \mathrm{MHz}\right): \delta 5.14(\mathrm{~m}), \delta 3.68(\mathrm{~s}, 1 \mathrm{H}), \delta 2.56(\mathrm{~d}$, $J=9.9 \mathrm{~Hz}, 1 \mathrm{H}), \delta 0.73(\mathrm{~s}, 3 \mathrm{H}), \delta 0.94(\mathrm{~s}, 3 \mathrm{H}), \delta 7.46(\mathrm{~d}, J=1.8 \mathrm{~Hz}$, $1 \mathrm{H}), \delta 7.90(\mathrm{dd}, J=9.8$ and $2.4 \mathrm{~Hz}, 1 \mathrm{H}), \delta 6.28(\mathrm{t}, J=9.6 \mathrm{~Hz}, 1 \mathrm{H})$, $\delta 4.28(\mathrm{dd}, J=8.4$ and $4.9 \mathrm{~Hz}, 1 \mathrm{H}), \delta 1.88(\mathrm{~m}, 2 \mathrm{H}), \delta 1.61(\mathrm{~m}, 2 \mathrm{H})$, $\delta 3.20(\mathrm{~m}, 2 \mathrm{H}), \delta 2.20-2.38(\mathrm{~m}, 4 \mathrm{H}), \delta 1.71(\mathrm{~m}, 4 \mathrm{H})$ and $\delta 1.36(\mathrm{~m}$, $4 \mathrm{H}) .{ }^{13} \mathrm{C} \mathrm{NMR}\left(\mathrm{CD}_{3} \mathrm{OD}-150 \mathrm{MHz}\right) \delta$ (ppm): 26.4, 25.7, 72.2, 36.4, 74.3, 36.1, 24.3, 33.9, 43.2, 41.6, 22.5, 39.7, 46.1, 75.7, 61.1, 27.7, $48.3,17.0,17.1,124.5,150.6,149.7,115.4,164.6,55.2,31.1,25.8$, 42.0, 174.8/175.7, 35.4/37.3, 26.3/26.6, 29.4/30.0, 178.8 and 158.6. The CRV-70 fraction (394.1 mg) was fractionated in silica gel column. The CRV-70-04 sub-fraction was analyzed by NMR and mass spectrometry, and its majority compound was identified as marinobufagin (3). Subsequently, this sub-fraction was submitted to purification by High Performance Liquid Chromatography (HPLC) using ultrapure water (eluent A) and acetonitrile (eluent B), the system was eluted in isocratic mode with $60 \%$ eluent $B$, obtaining the group MB-3 (7.9 mg), which was identified as bufalin (4). The spectral data of the isolated compounds are in accordance with the literature $[25,46,47,48]$ and described below. The structures are shown in Figure 1.

\section{Compound 3 (MB-1)}

Marinobufagin - molecular formula: $\mathrm{C}_{24} \mathrm{H}_{32} \mathrm{O}_{5}$; IT-ESI-MS $[\mathrm{M}+\mathrm{H}]^{+} 401.3 ;{ }^{1} \mathrm{H} \mathrm{NMR}\left(\mathrm{CDCl}_{3}-600 \mathrm{MHz}\right): \delta 4.16-4.19(\mathrm{~m}), \delta$ $3.49(\mathrm{~s}, 1 \mathrm{H}), \delta 2.46(\mathrm{~d}, J=10.1 \mathrm{~Hz}, 1 \mathrm{H}), \delta 0.77(\mathrm{~s}, 3 \mathrm{H}), \delta 0.97(\mathrm{~s}$, $3 \mathrm{H}), \delta 7.23(\mathrm{~d}, J=9.8 \mathrm{~Hz}, 1 \mathrm{H}), \delta 7.76(\mathrm{dd}, J=9.8$ and $2.5 \mathrm{~Hz}, 1 \mathrm{H})$ and $\delta 6.24(\mathrm{dd}, J=9.8$ and $0.8 \mathrm{~Hz}, 1 \mathrm{H}) .{ }^{13} \mathrm{C} \mathrm{NMR}\left(\mathrm{CDCl}_{3}-150\right.$ MHz): 24.9, 28.1, 68.1, 39.5, 74.7, 34.8, 23.4, 32.7, 42.8, 41.0, 21.6, $39.5,45.2,74.7,59.9,32.4,47.7,16.9,16.9,122.4,149.8,147.0$, 115.4 and 162.2 .

\section{Compound 4 (MB-3)}

Bufalin - molecular formula: $\mathrm{C}_{24} \mathrm{H}_{34} \mathrm{O}_{4}$; IT-ESI-MS $[\mathrm{M}+\mathrm{H}]^{+}$387.3; ${ }^{1} \mathrm{H} \mathrm{NMR}\left(\mathrm{CDCl}_{3}-600 \mathrm{MHz}\right): \delta 4.13-4.18(\mathrm{~m}), \delta 2.56(\mathrm{dd}, J=9.7$ and $6.6 \mathrm{~Hz}, 1 \mathrm{H}), \delta 0.69(\mathrm{~s}, 3 \mathrm{H}), \delta 0.94(\mathrm{~s}, 3 \mathrm{H}), \delta 7.22(\mathrm{~d}, J=1.8$ $\mathrm{Hz}, 1 \mathrm{H}), \delta 7.84(\mathrm{dd}, J=9.7$ and $2.6 \mathrm{~Hz}, 1 \mathrm{H})$ and $\delta 6.26(\mathrm{~d}, J=$ $9.7 \mathrm{~Hz}, 1 \mathrm{H}){ }^{13} \mathrm{C} \mathrm{NMR}\left(\mathrm{CDCl}_{3}-150 \mathrm{MHz}\right): 29.8,28.0,66.9,33.4$, $36.1,26.6,21.5,42.5,35.8,35.5,21.5,41.0,48.5,85.5,32.8,28.8$, $51.3,16.7,23.9,122.8,148.6,146.9,115.5$ and 162.6 .

\section{In silico: Virtual screening}

Table 1 shows the molecular targets, location, and enzymatic class of the 35 molecular targets obtained from the Tropical Disease Research (TDR targets database) for building the 
Brazilian Malaria Molecular Targets (BraMMT). The compounds (dehydrobufotenin, marinobufotoxin, marinobufagin, bufalin) were assayed for the docking methodology in the BraMMT data bank. Virtual screening performed against the 35 molecular targets in the database using OCTOPUS software presented 10 potential targets for all compounds tested (Table 2). These results were found when the binding energy values are lower than the crystallographic control.

PfHT is characterized as glucose transporter of $P$. falciparum. The docking, QM/MM and molecular dynamics simulations were already performed by our group $[49,50,51]$. The Figures 2, 3, 4, 5 and 6 shows $2 \mathrm{D}$ ligand-receptor interactions maps with PfHT. The figures show the chemicals bonds that occurred between the compound and the target, which enables the identification of pharmacophoric groups and possible structural improvements for better oral permeability, absorption, and bioavailability. The 3D binding diagram of the compounds is show in Figure 7. Docking with $D$-Glucose and PfHT was performed as a control.

Marinobufagin binds to 2-pyrone group in PfHT protein by residue ILE-176 while the perhydrophenanthrene nucleus binds by residues ILE-401 and PRO-149 (Figure 2). Marinobufotoxin binds to 2-pyrone group by residue VAL-144 while the perhydrophenanthrene nucleus binds by residues ILE-172 (Figure 3). Bufalin interacts with the protein electrostatically from the same active sites with residues ILE-141 and ILE-176 (Figure 4).

The compound dehydrobufotenin is an alkaloid derivative with consequent presence of the quinoline ring like the quinine and its analogs. Among the interactions involving the binding to the PfHT protein, the quinoline nucleus performs electrostatic bonding with the PRO149 residue (Figure 5). Although there is an unfavorable interaction between compound dehydrobufotenin and PfHT, this negative event is offset by other interactions.

$D$-glucose interacts in the same biding site of PfHT with electrostatic bonding in the residues GLN169 and THR145 (Figure 6).

Table 3 presents the information obtained from the physicalchemical properties by the DataWarrior software. The compound marinobufotoxin presented CLogP $<5$ (2.80), molecular mass was greater than $500(712.88 \mathrm{~g} / \mathrm{mol})$, the hydrogen accepting groups that performed interactions are more than 10 (13 groups), and the hydrogen donor groups are more than 5 (6 groups). Thus, based on the rules of Lipinski, compound marinobufotoxin is expected to present unfavorable pharmacokinetics properties (absorption, distribution, metabolization, excretion, and toxicity).

The compounds dehydrobufotenin, marinobufagin and bufalin presented molecular mass below $500(203.26 \mathrm{~g} / \mathrm{mol} ; 400.51 \mathrm{~g} / \mathrm{mol}$ and $383.53 \mathrm{~g} / \mathrm{mol}$, respectively), CLogP $<5$ (0.51; 1.87 and 2.99, respectively), less than 10 hydrogen acceptor groups ( 3 groups; 5 groups and 4 groups, respectively) and less than 5 hydrogen donor groups (2 groups). Thus, these results, based on the rules of Lipinski, the compounds dehydrobufotenin, marinobufagin and bufalin have sufficiently acceptable ADMET properties.

Gleeson [52] suggests in his study that compounds with CLogP less than 4 and molecular weight less than 400 have a more

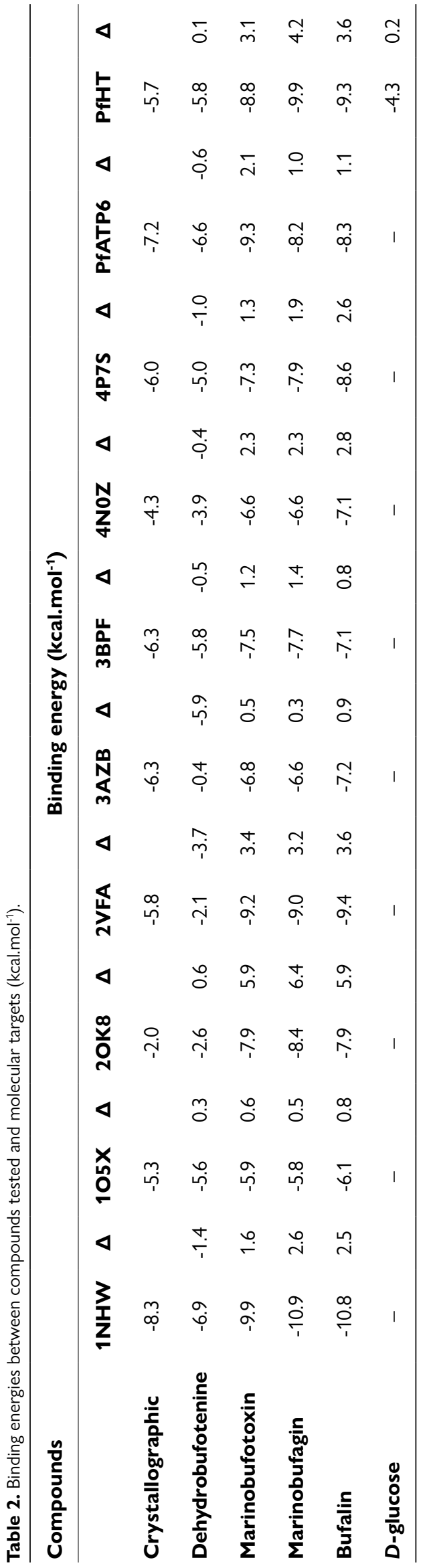




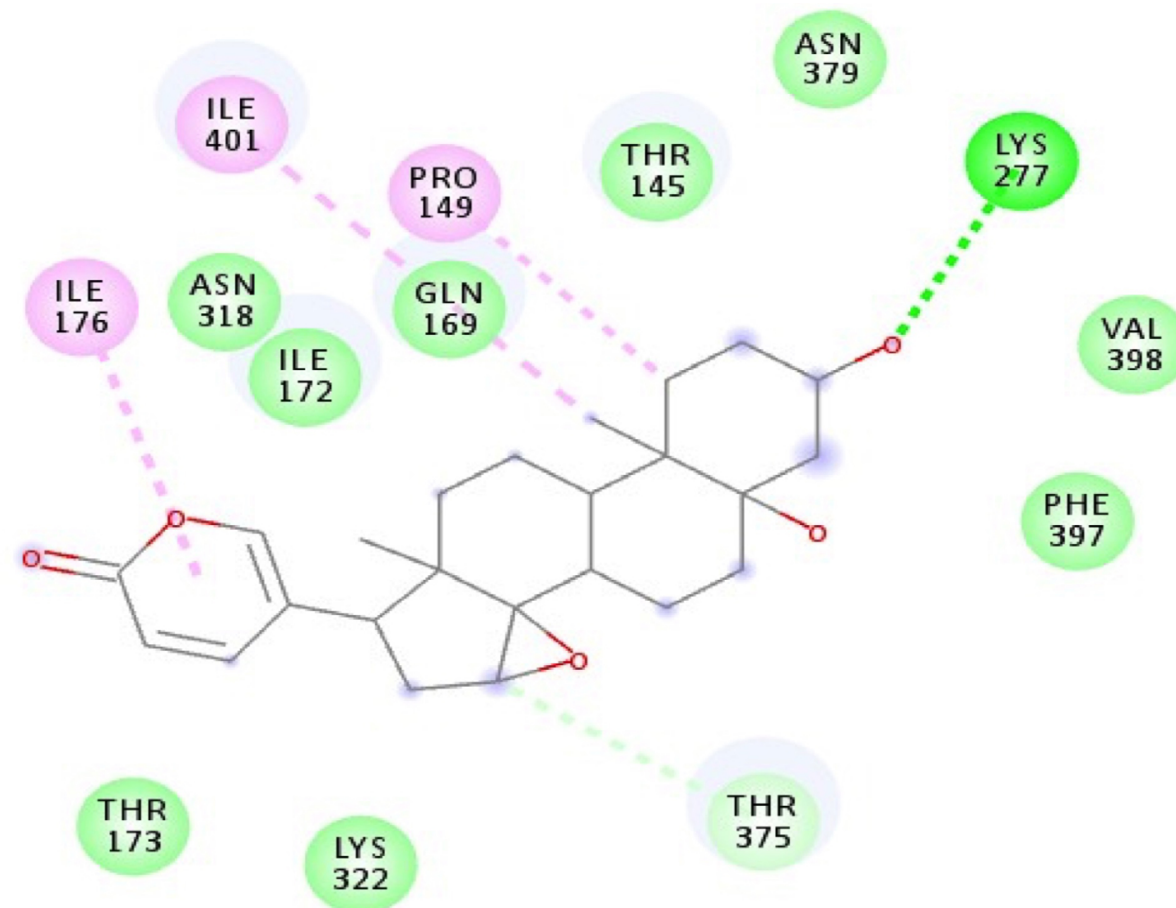

\section{Interactions}

$\square$ van der Waals

Conventional Hydrogen Bond

Figure 2. Residues in the active site of $\mathrm{PfHT}$ target interacting with the compound marinobufagin (MB-1).

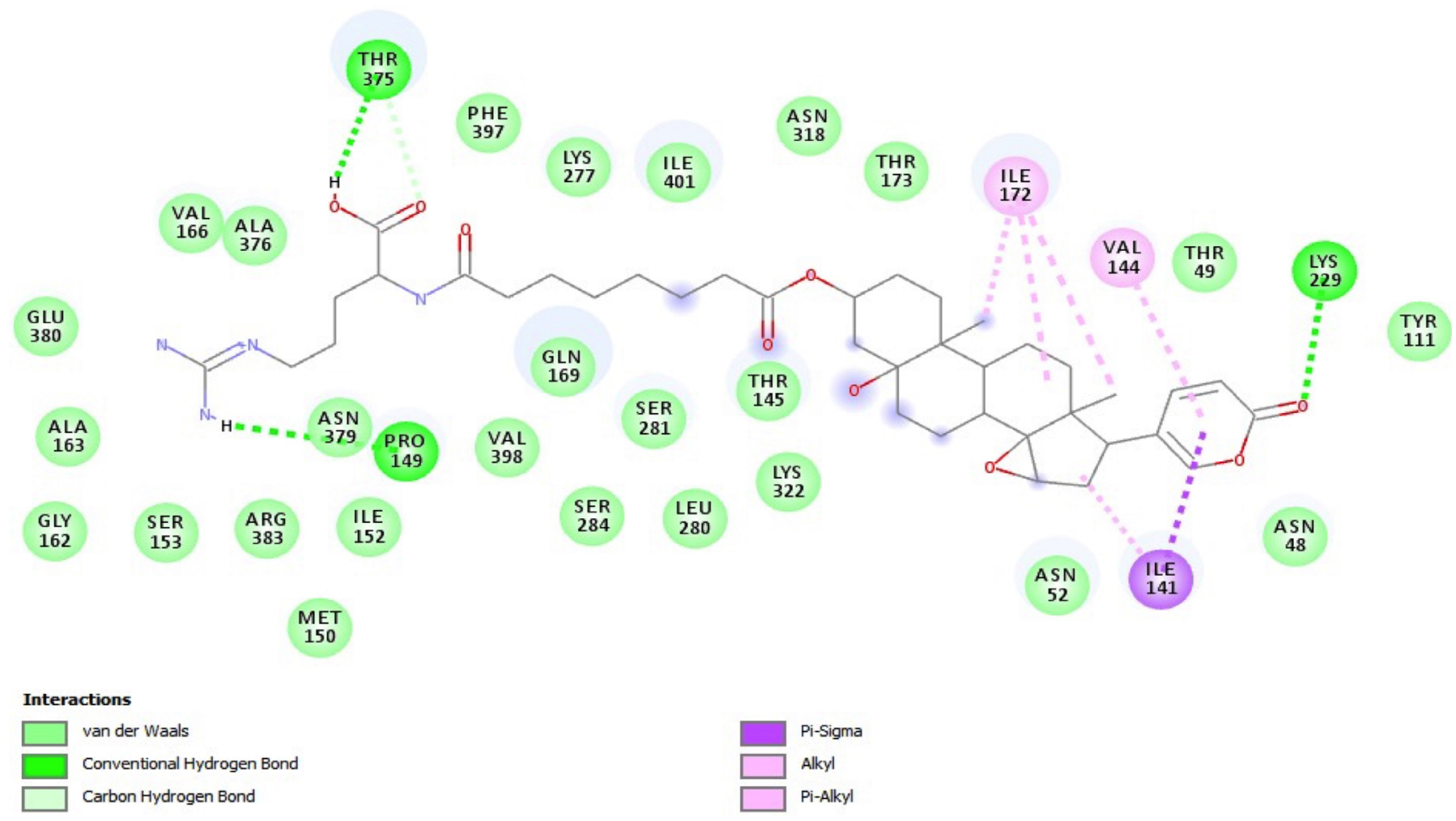

Figure 3. Residues in the active site of PfHT target interacting with compound the marinobufotoxin (CRV-6-21-58). 


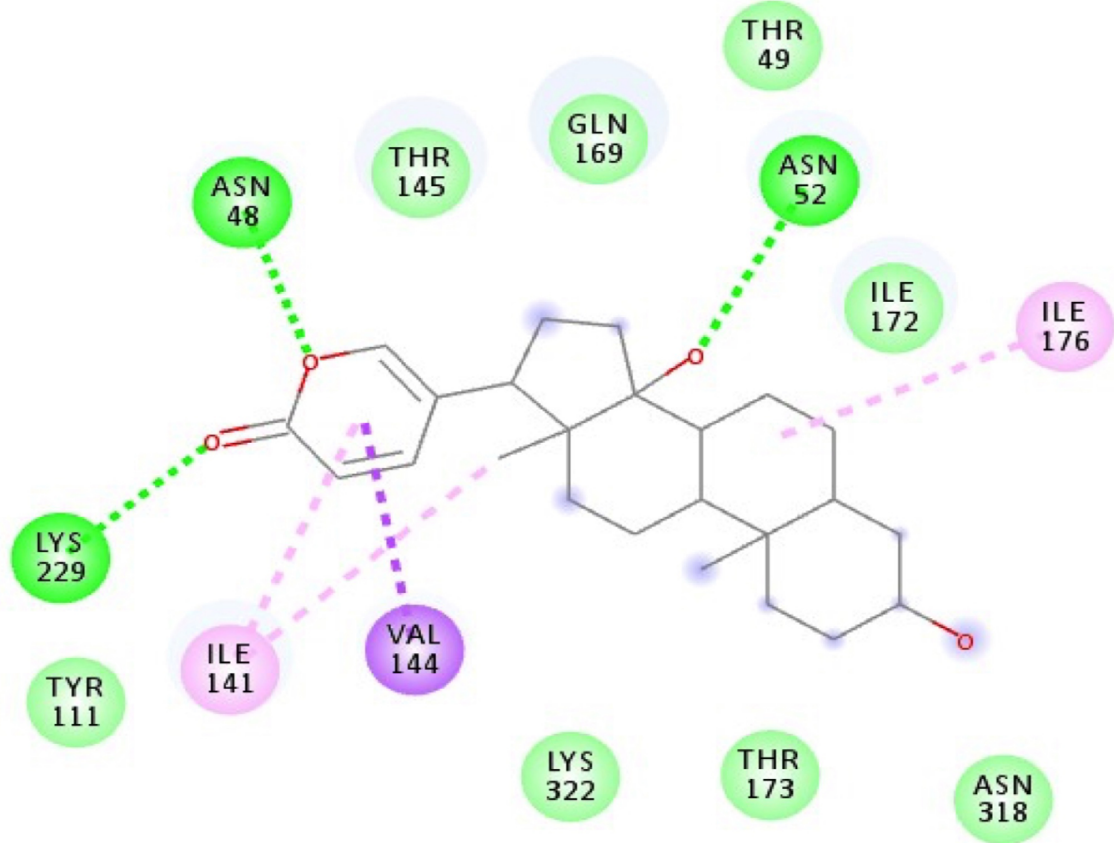

\section{Interactions}

$\square$ van der Waals
Conventional Hydrogen Bond
Pi-Sigma

Figure 4. Intermolecular interactions of the compound bufalin (MB-3) with PfHT.

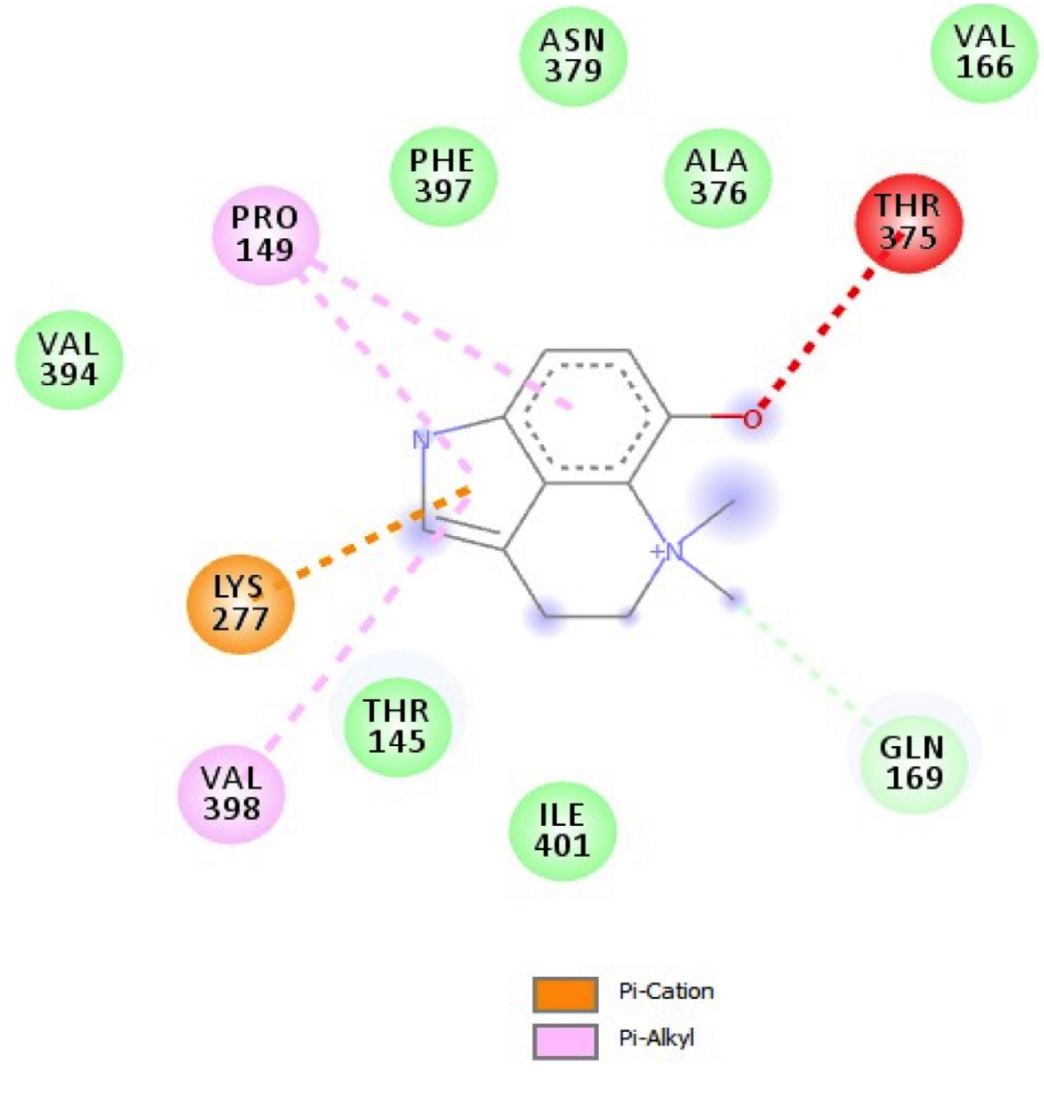

Figure 5. Intermolecular interactions of the compound dehydrobufotenine (CRV-28) with PfHT. 

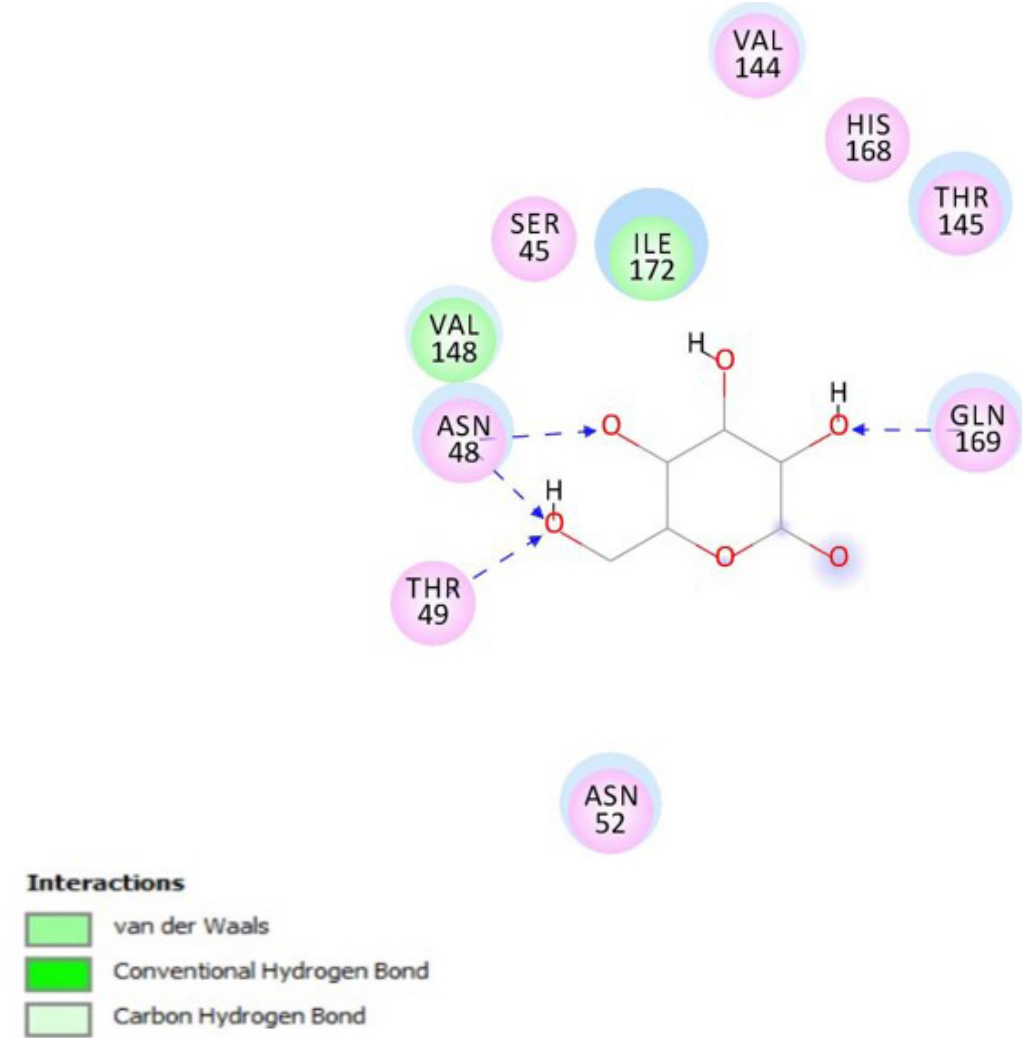

\section{Interactions}

Figure 6. Intermolecular interactions of $D$-glucose with $\mathrm{PfHT}$.
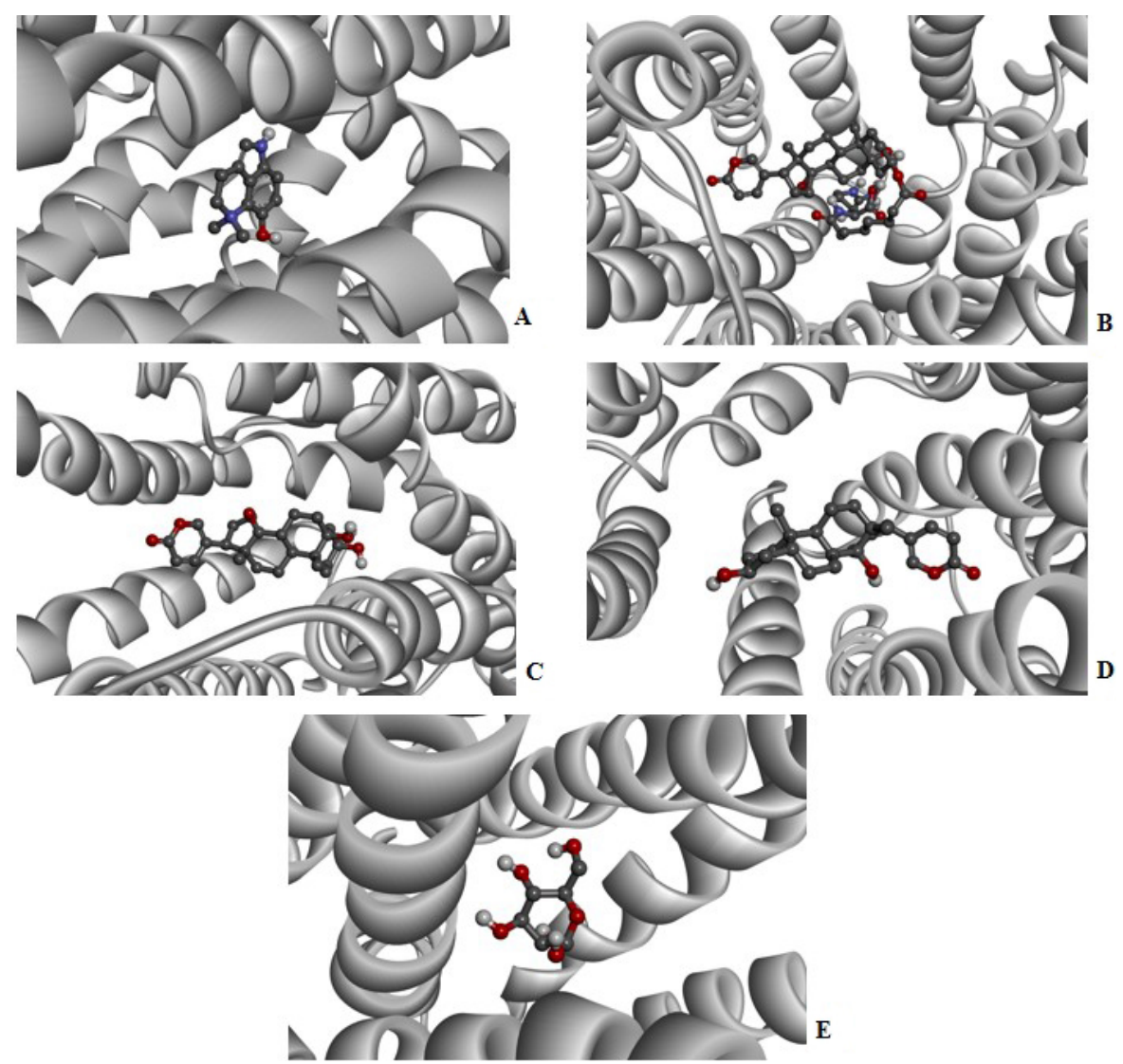

Figure 7. Three-dimensional structure of PfHT complexed with of $R$. marina venom fractions. (A) Dehydrobufotenine (CRV-28), (B) marinobufotoxin (CRV-621-58), (C) marinobufagin (MB-1), (D) bufalin (MB-3) and (E) $D$-glucose. 
favorable ADMET profile than those suggested by Lipinski. Following the Gleeson theory, all compounds have CLogP $<3$ and compounds dehydrobufotenin, marinobufagin and bufalin have molecular mass below 400 .

Toxicological characteristics of the four compounds using the DataWarrior software, factors such as mutagenicity, tumogenicity or irritability were not evidenced (Table 4).

\section{In vitro antiplasmodial activity}

The compounds dehydrobufotenin, marinobufotoxin, marinobufagin and bufalin diluted in DMSO were assayed for antiplasmodial activity against chloroquine-resistant $P$. falciparum W2. Table 5 shows the antiplasmodial activity of dehydrobufotenin, marinobufotoxin, marinobufagin and bufalin in two different experiments. Starting from $100 \mu \mathrm{g} / \mathrm{mL}$, the compounds were diluted to various concentrations $(0.78-100 \mu \mathrm{g} /$ $\mathrm{mL}$ ) to calculate the $\mathrm{IC}_{50}$ values. The samples (dehydrobufotenin, marinobufotoxin, marinobufagin and bufalin) showed $\mathrm{IC}_{50}$ values ranged from 3.44 to $19.11 \mu \mathrm{M}$ (Table 5). The marinobufagin and bufalin had the $\mathrm{IC}_{50}$ values close to chloroquine, the antimalarial used as a positive control.

\section{Cytotoxic activity on human pulmonary fibroblast cells}

To evaluate the cytotoxic activity of the compounds dehydrobufotenin, marinobufotoxin, marinobufagin and bufalin, the MTT assay conducted in human pulmonary fibroblast cells (WI-26VA4). It was observed that the compounds marinobufotoxin, marinobufagin and bufalin showed high cytotoxicity to this cell line with low $\mathrm{LD}_{50}$ values (marinobufotoxin $=8.89 \mu \mathrm{M}$; marinobufagin $=3.04 \mu \mathrm{M}$ and bufalin $=25.9 \mu \mathrm{M}$, respectively) while dehydrobufotenin showed low cytotoxic with high $\mathrm{LD}_{50}$ value $(235.76 \mu \mathrm{M})$ (Table 5).

Evaluating the selectivity index (SI), although compounds marinobufotoxin, marinobufagin and bufalin have shown potentially active, only the compound dehydrobufotenin showed high selectivity for the parasites when analyzed by MTT assay $(\mathrm{SI}>10)$ (Table 5).

\section{ADMET likeness properties}

Pharmacokinetic behavior of a compound can determine the success or failure of its biological activity [53]. New potential antimalarial candidates must present good oral bioavailability and good membrane permeability as properties that can lead

Table 3. Molecular mass ( $\mathrm{g} / \mathrm{mol})$, partition coefficient (CLogP), number of hydrogen donor groups and number of hydrogen acceptor groups of tested compounds.

\begin{tabular}{|c|c|c|c|c|}
\hline Compounds & Molecular mass & CLogP & $\mathrm{H}^{+}$Acceptors & $\mathrm{H}^{+}$Donors \\
\hline Dehydrobufotenine & 203.26 & 0.51 & 3 & 2 \\
\hline Marinobufotoxin & 712.88 & 2.80 & 13 & 6 \\
\hline Marinobufagin & 400.51 & 1.87 & 5 & 2 \\
\hline Bufalin & 386.53 & 2.99 & 4 & 2 \\
\hline
\end{tabular}

Table 4. Toxicological characteristics of compounds obtained from $R$. marina venom.

\begin{tabular}{lcc}
\hline Compounds & Mutagenicity & Tumorgenicity \\
\hline Dehydrobufotenine & Absent & Absent \\
Marinobufotoxin & Absent & Absent \\
Marinobufagin & Absent & Absent \\
Bufalin & Absent & Absent \\
\hline
\end{tabular}

Table 5. The lethal drug concentration that reduced parasite viability in $50 \%\left(\mathrm{IC}_{50}\right)$, lethal drug concentration that reduced $\mathrm{WI}-26 \mathrm{VA} 4$ cells viability in $50 \%$ (LD $\left.{ }_{50}\right)$, and selectivity index (SI) values obtained from in vitro tests with venom fractions from $R$. marina venom, and chloroquine (CQ) against $P$. falciparum W2 strain.

\begin{tabular}{|c|c|c|c|}
\hline Compounds & $I C_{50} \pm S D(\mu M) *$ & $\operatorname{LD}_{50}{ }^{a} \pm \operatorname{SD}(\mu \mathrm{M}) *$ & $\mathbf{S} \mathbf{l}^{\mathbf{a}}$ \\
\hline Dehydrobufotenine & $19.11 \pm 0.20$ & $235.76 \pm 4.03$ & 12.33 \\
\hline Marinobufotoxin & $5.31 \pm 0.25$ & $8.89 \pm 2.66$ & 1.67 \\
\hline Marinobufagin & $3.89 \pm 0.42$ & $3.04 \pm 0.25$ & 0.78 \\
\hline Bufalin & $3.44 \pm 0.43$ & $25.9 \pm 7.04$ & 7.52 \\
\hline Chloroquine (CQ) & $1.04 \pm 0.21$ & $>100$ & $>100$ \\
\hline
\end{tabular}

$\mathrm{LD}_{50}$ and $\mathrm{SI}$ values were obtained with MTT cytotoxic test in human pulmonary fibroblast cells (WI-26VA4).

*Mean and standard deviation (SD) of triplicate experiments. 
the in vivo experiments to reach success [54]. In this sense, SwissADME web tool [30] allows an in silico inference of the main physical-chemical and pharmacokinetic properties of the compounds. In Table 6 are presented the SwissADME profile of the four compounds.

Bufalin, the most active compound, exhibits numbers of hydrogen bond acceptors (NHA) and hydrogen bond donors (NHD) in accordance with the rule of five by Lipinski. The LogS predicition of bufalin is -5.2, comparable with chloroquine (-6.92), indicating a good solubility. Although, the predicted polar surface area (PSA) of $70.67 \AA 2$ for bufalin suggests that the polarity of this compound is a limiting factor for oral bioavailability [55]. In counterpoint, the synthetic accessibility of bufalin (5.56) is within the range of a non-complicated synthetic accessibility. bufalin could be a potential template for new antimalarial candidates.

\section{Discussion}

The drug discovery process is a major challenge in the pharmaceutical science due the time and money employed in all the phases of developing of a new drug entity [31]. Aiming to reduce cost and time in this process, structure-based virtual screening is an important in silico technique for drug design [56]. In this context, BraMMT database with 35 molecular targets of Plasmodium falciparum was used in this work. Table 1 shows all the targets and location of the proteins that were used for in silico binding assays with compounds isolated from $R$. marina. Three compounds interacted significantly with 10 potential targets (Table 2).

Of all 35 potential targets of BraMMT, the hexose transporter of Plasmodium falciparum (PfHT) interacted significantly with all tested compounds (Table 2). The target PfHT is a membrane protein of the parasite responsible for glucose transport. During the biological development of the parasites in the host's red

Table 6. Physicochemical properties of dehydrobufotenin, marinobufotoxin, marinobufagin, bufalin and the antimalarial chloroquine according to SwissADME web tool.

\begin{tabular}{|c|c|c|c|c|c|}
\hline $\begin{array}{l}\text { PHYSICOCHEMICAL } \\
\text { PROPERTIES }\end{array}$ & Dehydrobufotenine & Marinobufotoxin & Marinobufagin & Bufalin & Chloroquine \\
\hline Formula & $\mathrm{C} 12 \mathrm{H} 15 \mathrm{~N} 2 \mathrm{O}$ & $\mathrm{C} 38 \mathrm{H} 56 \mathrm{~N} 4 \mathrm{O} 9$ & $\mathrm{C} 24 \mathrm{H} 32 \mathrm{O} 5$ & $\mathrm{C} 24 \mathrm{H} 34 \mathrm{O} 4$ & $\mathrm{C} 18 \mathrm{H} 26 \mathrm{CIN} 3$ \\
\hline Molecular weight & $203.26 \mathrm{~g} / \mathrm{mol}$ & $712.87 \mathrm{~g} / \mathrm{mol}$ & $400.51 \mathrm{~g} / \mathrm{mol}$ & $386.52 \mathrm{~g} / \mathrm{mol}$ & $319.87 \mathrm{~g} / \mathrm{mol}$ \\
\hline Num. heavy atoms & 15 & 51 & 29 & 28 & 22 \\
\hline Num. arom heavy atoms & 9 & 6 & 6 & 6 & 10 \\
\hline Fractions Csp3 & 0.33 & 0.76 & 0.79 & 0.79 & 0.50 \\
\hline Num. rotable bonds & 0 & 18 & 1 & 1 & 8 \\
\hline Num. H-bond acceptors & 2 & 10 & 5 & 4 & 2 \\
\hline Num. H-bond donors & 2 & 6 & 2 & 2 & 1 \\
\hline Molar Refractivity & 66.18 & 190.16 & 108.86 & 109.86 & 97.41 \\
\hline TPSA & $36.02 \AA^{2}$ & $217.57 \AA^{2}$ & $83.20 \AA^{2}$ & $70.67 \AA^{2}$ & $28.16 \AA^{2}$ \\
\hline \multicolumn{6}{|l|}{ LIPOPHILICITY } \\
\hline $\log P_{\text {olw }}($ ILOGP $)$ & -1.27 & 3.47 & 3.27 & 3.34 & 3.95 \\
\hline $\log P_{\text {olw }}($ XLOGP3) & 1.64 & 3.23 & 2.50 & 3.2 & 4.63 \\
\hline $\log P_{\text {olw }}($ WLOGP $)$ & 1.62 & 4.10 & 3.37 & 4.24 & 4.62 \\
\hline $\log P_{\text {olw }}(M L O G P)$ & -2.19 & 2.12 & 2.75 & 3.58 & 3.20 \\
\hline $\log P_{\text {olw }}($ SILICOS-IT) & 2.15 & 4.89 & 3.82 & 3.99 & 4.32 \\
\hline Consensus $\log P$ olw & 0.39 & 3.56 & 3.14 & 3.67 & 4.15 \\
\hline \multicolumn{6}{|l|}{ WATER SOLUBILITY } \\
\hline $\log S(E S O L)$ & -2.58 & -5.19 & -3.99 & -4.35 & -4.55 \\
\hline Solubility & $\begin{array}{c}5.38 \mathrm{e}-01 \mathrm{mg} / \mathrm{mL} \\
2.65 \mathrm{e}-03 \mathrm{~mol} / \mathrm{L}\end{array}$ & $\begin{array}{l}4.56 \mathrm{e}-03 \mathrm{mg} / \mathrm{mL} \\
6.40 \mathrm{e}-06 \mathrm{~mol} / \mathrm{L}\end{array}$ & $\begin{array}{c}4.14 \mathrm{e}-02 \mathrm{mg} / \mathrm{mL} ; \\
1.03 \mathrm{e}-04 \mathrm{~mol} / \mathrm{L}\end{array}$ & $\begin{array}{c}1.75 \mathrm{e}-02 \mathrm{mg} / \mathrm{mL} ; \\
4.52 \mathrm{e}-05 \mathrm{~mol} / \mathrm{L}\end{array}$ & $\begin{array}{l}9.05 \mathrm{e}-03 \mathrm{mg} / \mathrm{mL} \\
2.83 \mathrm{e}-05 \mathrm{~mol} / \mathrm{L}\end{array}$ \\
\hline Class & Soluble & Moderately soluble & Soluble & $\begin{array}{l}\text { Moderately } \\
\text { soluble }\end{array}$ & Moderately soluble \\
\hline $\log S(A l i)$ & -2.01 & -7.47 & -3.89 & -4.36 & -4.95 \\
\hline Solubility & $\begin{array}{c}1.99 \mathrm{e}+00 \mathrm{mg} / \mathrm{mL} \\
9.78 \mathrm{e}-03 \mathrm{~mol} / \mathrm{L}\end{array}$ & $\begin{array}{c}2.40 \mathrm{e}-05 \mathrm{mg} / \mathrm{mL} \\
3.37 \mathrm{e}-08 \mathrm{~mol} / \mathrm{L}\end{array}$ & $\begin{array}{l}5.13 \mathrm{e}-02 \mathrm{mg} / \mathrm{mL} \\
1.28 \mathrm{e}-04 \mathrm{~mol} / \mathrm{L}\end{array}$ & $\begin{array}{l}1.70 \mathrm{e}-02 \mathrm{mg} / \mathrm{mL} \\
4.41 \mathrm{e}-05 \mathrm{~mol} / \mathrm{L}\end{array}$ & $\begin{array}{l}3.61 \mathrm{e}-03 \mathrm{mg} / \mathrm{mL} \\
1.13 \mathrm{e}-05 \mathrm{~mol} / \mathrm{L}\end{array}$ \\
\hline
\end{tabular}


Table 6. Cont.

\begin{tabular}{|c|c|c|c|c|c|}
\hline $\begin{array}{l}\text { PHYSICOCHEMICAL } \\
\text { PROPERTIES }\end{array}$ & Dehydrobufotenine & Marinobufotoxin & Marinobufagin & Bufalin & Chloroquine \\
\hline Class & Soluble & Poorly soluble & Soluble & $\begin{array}{l}\text { Moderately } \\
\text { soluble }\end{array}$ & Moderately soluble \\
\hline Log S (SILICOS-IT) & -4.09 & -7.46 & -4.73 & -5.2 & -6.92 \\
\hline Solubility & $\begin{array}{l}1.63 \mathrm{e}-02 \mathrm{mg} / \mathrm{mL} \\
8.04 \mathrm{e}-05 \mathrm{~mol} / \mathrm{L}\end{array}$ & $\begin{array}{l}2.45 \mathrm{e}-05 \mathrm{mg} / \mathrm{mL} \\
3.44 \mathrm{e}-08 \mathrm{~mol} / \mathrm{L}\end{array}$ & $\begin{array}{l}\text { 7.42e-03 mg/mL; } \\
1.85 \mathrm{e}-05 \mathrm{~mol} / \mathrm{L}\end{array}$ & $\begin{array}{l}3.68 \mathrm{e}-03 \mathrm{mg} / \mathrm{mL} \\
9.53 \mathrm{e}-06 \mathrm{~mol} / \mathrm{L}\end{array}$ & $\begin{array}{l}3.86 \mathrm{e}-05 \mathrm{mg} / \mathrm{mL} \\
1.21 \mathrm{e}-07 \mathrm{~mol} / \mathrm{L}\end{array}$ \\
\hline Class & Moderately soluble & Poorly soluble & Moderately soluble & $\begin{array}{l}\text { Moderately } \\
\text { soluble }\end{array}$ & Poorly soluble \\
\hline
\end{tabular}

\section{PHARMACOKINETICS}

Gl absorption
BBB permeant
P-gP substrate
CYP1A2 inhibitor
CYP2C19 inhibitor
CYP2C9 inhibitor
CYP2D6 inhibitor
CYP3A4 inhibitor
Log Kp (skin permeation)

\section{DRUGLIKENESS}

Lipinski

Ghose

Veber

Egan

Muegge

Biovailability Score

MEDICINAL CHEMISTRY

PAINS

Brenk

Leandlikeness

Synthetic accessibility

High
Yes
Yes
Yes
No
No
No
No
$-6.38 \mathrm{~cm} / \mathrm{s}$

Yes; 0 violation

Yes

Yes

Yes

Yes

0.55

0 alert

1 alert quaternary_ nitrogen_2

No; 1 violation: $M W<250$
No; 3 violations: $M W>500$,

NorO $>10$, $\mathrm{NHorOH}>5$

No; 3 violations: $M W>500$, NorO $>10$, $\mathrm{NHorOH}>5$

No; 2 violations: Rotors $>10$, TPSA $>140$

No; 1 violation: TPSA $>131.6$

No; 4 violations: $M W>600$, TPSA>150, Rotors $>15$, $\mathrm{H}$-don $>5$

$$
0.17
$$

0 alert

3 alerts: Threemembered_ heterocycle, imine_1, imine_2

No; 2 violations: $M W>350$, Rotors $>7$
Yes; 0 violation Yes; 0 violation Yes; 0 violation

Yes

Yes

Yes

Yes

Yes

Yes

Yes

Yes

Yes

Yes

Yes

Yes

0.55

0.55

0.55

0 alert

0 alert

0 alert

1 alert: Threemembered_ heterocycle

0 alert

0 alert

No; 1 violation: $M W>350$

No; 1 violation: $M W>350$

No; 2 violations: Rotors $>7$, XLOGP3>3.5 
blood cells, the plasmodium requires glucose whose uptake is driven by carrier proteins. In red blood cells infected by $P$. falciparum glucose consumption is increased provided by PfHT. Inhibition of glucose transport to infected red blood cells impairs the parasite's metabolism, leading to death. Therefore, compounds that inhibit PfHT can be considered promising in the development of new bioactive compounds capable of treating malaria infections [53]. Additional potential targets analyzed are related to other structures of the parasite, such as apicoplast, cytoplasm, digestive vacuole, and sarcoplasmic reticulum.

The $\mathrm{PfHT}$ protein is a $P$. falciparum hexose transporter. Figures $2,3,4,5$ and 6 show the interaction of test compounds with PfHT. It is possible to visualize in the figures the chemical bonds that occurred between the compound and the target. All compounds interact at the same PfHT binding site of $D$-glucose [53] with residues GLN169 and THR145. The compounds interact with the PfHT receptor mainly through Van der Walls interactions, hydrogen bonds, and electrostatic bonds.

Figures 2, 3 and 4 shows that the electrostatic bonds interact with the PfHT receptor by the 2-pyrone group and the perhydrophenanthrene nucleus, demonstrating that the expression of antimalarial activity is associated with the presence of these structures. These groups are common to bufodianolides suggesting that the expression of antimalarial activity is associated with the presence of these structures.

One of the parameters introduced in the rational development of new drugs is Lipinski's rules "rule of five". These parameters include molecular weight (M.M.) $\leq 500 \mathrm{~g} / \mathrm{mol}$, number of hydrogen bonding donor atoms $\leq 5$, number of hydrogen bond acceptor atoms $\leq 10$, and calculated octanol/water partition coefficient $(c \log \mathrm{P}) \leq 5$ [42]. The partition coefficient (CLogP) is a measure of the lipophilicity of a substance related to the interaction of the compound with the medium. This is an important tool regarding the study of absorption and transport. Furthermore, the program for the evolution of hazardous compounds recommends this measure, as it also provides estimates of toxicological factors [57].

Gleeson [58] suggests in his study that compounds with CLogP less than 4 and molecular weight less than 400 have a more favorable ADMET profile than those suggested by Lipinski. Following the Gleeson theory, all compounds have CLogP $<4$ and compounds dehydrobufotenin, marinobufagin and bufalin have molecular mass below 400 . Therefore, these three compounds (dehydrobufotenin, marinobufagin and bufalin) also fit Gleeson's theory. Therefore, compounds dehydrobufotenin, marinobufagin and bufalin showed sufficiently acceptable absorption, distribution, metabolism, excretion, and toxicity properties, according to Lipinski's rule and Gleeson's theory.

Compounds with high molecular weight and with an excessive number of hydrogen acceptor and donor groups, have greater difficulty in crossing the lipid bilayer of cell membranes. This is because such characteristics increase the lipophilicity of the compound, hindering solubility, and therefore impacting and the drug oral bioavailability [59]. Based in all these definitions, among the four compounds investigated in this study, the dehydrobufotenin was the one that presented the most favorable ADMET properties.

Secretions from 2 toad species, R. marina and R. guttatus, were chemically investigated previously. Two extracts and a pure substance (telocinobugagin) presented potential antimalarial activity [18]. When analyzed the $\mathrm{IC}_{50}$ values of all compounds tested ensure that $\mathrm{IC}_{50}$ values for the tested compounds ranged from $3.44 \mu \mathrm{M}$ to $19.11 \mu \mathrm{M}$ (dehydrobufotenin, marinobufotoxin, marinobufagin and bufalin).

According Mahmoudi [60], a potentially effective antimalarial compound possess an $\mathrm{IC}_{50}$ than $10 \mu \mathrm{M}$. The results published by Torres [52], indicated that alkaloids isolated from different parts of the Aspidosperma ulei plants, were moderately active against $P$. falciparum. These compounds presented $\mathrm{IC}_{50}$ values close to $20 \mu \mathrm{M}$. Based on this theories, the compounds marinobufotoxin $(5.31 \mu \mathrm{M})$, marinobufagin and bufalin (3.89 $\mu \mathrm{M}$ and $3.44 \mu \mathrm{M}$, respectively) were considered potentially active while dehydrobufotenin $(19.11 \mu \mathrm{M})$ expresses moderate activity.

The compounds marinobufotoxin, marinobufagin and bufalin showed cytotoxic activities against human pulmonary fibroblast cells (WI-26VA4) in MTT assay $\left(\mathrm{LD}_{50}=8.89 \mu \mathrm{M} ; 3.04 \mu \mathrm{M}\right.$ and $25.9 \mu \mathrm{M}$, respectively). These results corroborate with previous studies that have reported a higher cytotoxic activity of venom extracts from R. marina in comparison to those from R. guttatus due the presence of 2 other bufadienolides (telocinobufagin, and resibufogenin) [13]. Similarly, extracts of $R$. marina venom from Peruvian Amazon with different compositions showed higher cytotoxic activity in antiproliferative tests with different tumor cell lines [21].

In our study the dehydrobufotenin compound showed the highest $\mathrm{LD}_{50}$ value $(235.76 \mu \mathrm{M})$, indicating no cytotoxic effect against human pulmonary fibroblast cells. Low cytotoxicity of the bufadienolides fractions (telocinobufagin) against cancer cell lines (HL-60, SF-295, MDA-MB-435, and HCT-8) was also demonstrated [61]. However, to date, this was the first time that isolated dehydrobufotenine molecule was evaluated in cytotoxic test.

According to Bézivin [62], values higher than $10(\mathrm{SI}>10)$ is indicative of high selectivity values, whereas values below 10 $(\mathrm{SI}<10)$ are considered as low selectivity. In this study, although compounds 2, 3 and 4 were shown to be potentially active, only compound 1 was selective for the parasite, as it presented a selectivity index value greater than 10 (IS> 200).

In this work, it was important to assess the cytotoxic activity and evaluate the selectivity index for testing natural compounds with possible antimalarial potential. The exclusive observation of the $\mathrm{IC}_{50}$ values would result in wrong conclusions about the antimalarial potential of the compounds.

\section{Conclusions}

In summary, in docking assay all compounds tested promoted interaction between ligand-receptor with 10 targets of $P$. 
falciparum. Although in silico assays predicted good absorption, permeability, and absence of toxicity for three test compounds, in vitro assays demonstrated that only one compound expressed antimalarial activity and absence of cytotoxicity. The compound dehydrobufotenin can serve as a prototype molecule for the development of more active compounds.

\section{Abbreviations}

BraMMT: Brazilian Malaria Molecular Targets; DMSO: dimethyl sulfoxide; IBAMA: Brazilian Institute of Environment and Renewable Natural Resources; SISBIO: System for authorization of collection of biological material.

\section{Availability of data and materials}

All data generated or analyzed during this study are included in this published article.

\section{Funding}

This work was financially supported by the State of Mato Grosso Research Foundation (FAPEMAT), resource from the Universal Call for Proposals no. 042/2016 and State of Minas Gerais Research Foundation (FAPEMIG). The present work was carried out with the support of the Coordination for the Improvement of Higher Education Personnel (CAPES), financing code 001 . The authors thank CAPES postdoctoral fellowship of the Graduate Program in Pharmaceutical Sciences. They are also thankful for the financial support of $\mathrm{CNPq}$ and $\mathrm{CNPq} /$ INCTBioNat (465637/2014-0), and CAPES (1776790/2017-0).

\section{Competing interests}

The authors declare that they have no competing interests.

\section{Authors' contributions}

FFB and GCK contributed to the investigation, methodology, study conception and design, data interpretation, article drafting and writing. FFB and ALF were responsible for data acquisition and interpretation, the literature review and article drafting. DMJ contributed to material collection. SNA and MAR were responsible for assisting in vitro tests. MHC, ESMF and GMVJ contributed to preparation of venom extracts and isolation. RRN and AGT contributed to docking assays. WVC contributed with physicochemical properties analysis and interpretation. BAMS and FPV was a contributor in data acquisition and interpretation, and article drafting. All authors read and approved the final manuscript

\section{Ethics approval}

All experiments were performed according to internationally accepted guidelines for the care and use of laboratory animals. The present study was approved by the Federal University of Mato
Grosso Institutional Animal Care and Use Committee (protocol 23108.700260/14-7) and National System for the Management of Genetic Heritage and Associated Traditional Knowledge (SisGen AE 19081).

\section{Consent for publication}

Not applicable.

\section{References}

1. White NJ, Pukrittayakamee S, Hien TT, Faiz MA, Mokuolu OA, Dondorp AM. Malaria. Lancet. 2014 Feb 22;383(9918):723-35.

2. Naß J, Efferth T. Development of artemisinin resistance in malaria therapy. Pharmacol Res. 2019 Aug;146:104275.

3. Nosten F, White NJ. Artemisinin-based combination treatment of falciparum malaria. Am J Trop Med Hyg. 2007 Dec;77(6 Suppl):181-92.

4. Ocan M, Akena D, Nsobya S, Kamya MR, Senono R, Kinengyere AA, et al. Persistence of chloroquine resistance alleles in malaria endemic countries: a systematic review of burden and risk factors. Malar J. 2019 Mar 12;18(1):76.

5. White N. Antimalarial drug resistance and combination chemotherapy. Philos Trans R Soc Lond B Biol Sci. 1999 Apr 29;354(1384):739-49.

6. White NJ. Antimalarial drug resistance. J Clin Invest. 2004 Apr 15;113(8):1084-92.

7. Bakhiet AMA, Abdelraheem MH, Kheir A, Omer S, Gismelseed L, AbdelMuhsin AA, et al. Evolution of Plasmodium falciparum drug resistance genes following artemisinin combination therapy in Sudan. Trans R Soc Trop Med Hyg. 2019 Nov 1;113(11):693-700.

8. Veiga-Júnior VF, Pinto AC, Maciel MAM. Plantas Medicinais: Cura segura? Quím Nova. 2005 May-Jun;28(3):519-28.

9. World Health Organization. The African health monitor: African traditional medicine day. [cited 12 September 2019]. Available from: http://apps.who. int/medicinedocs/documents/s21374en/s21374en.pdf.

10. Lev E. Traditional healing with animals (zootherapy): medieval to presentday Levantine practice. J Ethnopharmacol. 2003 Mar; 85(1):107-118.

11. Kowalski K, Marciniak P, Rosinski G, Richlik L. Toxic activity and protein identification from the parotoid gland secretion of the common toad Bufo bufo. Comp Biochem Physiol C Toxicol Pharmacol. 2018 Feb;205:43-52.

12. Shibao PYT, Cologna CT, Morandi-Filho R, Wiezel GA, Fujimura PT, Ueira-Vieira C, et al. Deep sequencing analysis of toad Rhinella schneideri skin glands and partial biochemical characterization of its cutaneous secretion. J Venom Anim Toxins incl Trop Dis. 2018;24:36. doi: 10.1186/ s40409-018-0173-8.

13. Ferreira PM, Lima DJ, Debiasi BW, Soares BM, Machado Kda C, Noronha Jda C, et al. Antiproliferative activity of Rhinella marina and Rhaebo gutattus venom extracts from Southern Amazon. Toxicon. 2013 Sep;72:43-51.

14. Sousa LQ, Machado KDC, Oliveira SF, Araújo LD, Monção-Filho ED, Melo-Cavalcante AA, et al. Bufadienolides from amphibians: A promising source of anticancer prototypes for radical innovation, apoptosis triggering and $\mathrm{Na}+/ \mathrm{K}+-A T P a s e$ inhibition. Toxicon. 2017 Mar 1;127:63-76.

15. Machado KDC, Sousa LQ, Lima DJB, Soares BM, Cavalcanti BC, Maranhão SS, et al. Marinobufagin, a molecule from poisonous frogs, causes biochemical, morphological and cell cycle changes in human neoplasms and vegetal cells. Toxicol Lett. 2018 Mar 15;285:121-31.

16. Wang DL, Qi FH, Tang W, Wang FS. Chemical constituents and bioactivities of the skin of Bufo bufo gargarizans Cantor. Chem Biodivers. 2011 Apr;8(4):559-67.

17. Vigerelli H, Sciani JM, Jared C, Antoniazzi MM, Caporale GM, da Silva Ade $\mathrm{C}$, et al. Bufotenine is able to block rabies virus infection in BHK-21 cells. J Venom Anim Toxins incl Trop Dis. 2014 Oct 13;20(1):45. doi: https:// doi.org/10.1186/1678-9199-20-45. 
18. Banfi FF, Guedes KS, Andrighetti CR, Aguiar AC, Debiase BW, Noronha JC, et al. Antiplasmodial and Cytotoxic Activities of Toad Venoms from Southern Amazon, Brazil. Korean J Parasitol. 2016 Aug;54(4):415-21.

19. Kerkhoff J, Noronha JC, Bonfilio R, Sinhorin AP, Rodrigues DJ, Chaves $\mathrm{MH}$, et al. Quantification of bufadienolides in the poisons of Rhinella marina and Rhaebo guttatus by HPLC-UV. Toxicon. 2016 Sep 1;119:311-8.

20. Vigerelli $H$, Sciani JM, Pereira PMC, Lavezo AA, Silva ACR, Collaço RCO, et al. Bufotenine, a tryptophan-derived alkaloid, suppresses the symptoms and increases the survival rate of rabies-infected mice: the development of a pharmacological approach for rabies treatment. J Venom Anim Toxins incl Trop Dis. 2020 Feb 3;26:e20190050. https://doi.org/10.1590/16789199-jvatitd-2019-0050.

21. Schmeda-Hirschmann G, Quispe C, Arana GV, Theoduloz C, Urra FA, Cárdenas C. Antiproliferative activity and chemical composition of the venom from the Amazonian toad Rhinella marina (Anura: Bufonidae). Toxicon. 2016 Oct;121:119-29.

22. Abdelfatah S, Lu X, Schmeda-Hirschmann G, Efferth T. Cytotoxicity and antimitotic activity of Rhinella schneideri and Rhinella marina venoms. J Ethnopharmacol. 2019 Oct 5;112049.

23. Cunha Neto Rdos S, Vigerelli H, Jared C, Antoniazzi MM, Chaves LB, da Silva Ade C, et al. Synergic effects between ocellatin-F1 and bufotenine on the inhibition of BHK-21 cellular infection by the rabies virus. J Venom Anim Toxins Incl Trop Dis. 2015 Dec 2;21:50. doi: 10.1186/s40409-015-0048-1.

24. Panda S, Swaminathan S, Hyder KA, Christophel EM, Pendse RN, Sreenivas AN, et al. Drug resistance in malaria, tuberculosis, and HIV in South East Asia: biology, programme, and policy considerations. BMJ. 2017 Sep 5;358:j3545.

25. Barreiro EJ, Fraga CAM, Miranda ALP, Rodrigues CR. A química medicinal de N-acilidrazonas: Novos compostos-protótipos de fármacos analgésicos, anti-inflamatórios e antitrombóticos. Quím Nova. 2002;25(1):129-48.

26. Asokkumar K, Prathyusha LT, Umamaheshwari M, Sivashanmugam T, Subhadradevi $\mathrm{V}$, Jagannath $\mathrm{P}$, et al. Design, ADMET and docking studies on some novel chalcone derivatives as soluble epoxide hydrolase enzyme inhibitors. J Chil Chem Soc. 2012;57(4):1442-6.

27. Carvalho I, Pupo MT, Borges ÁDL. Introdução a modelagem molecular de fármacos no curso experimental de química farmacêutica. Quím Nova. 2003 May-Jun;26(3):428-38.

28. Guantai E, Chibale K. How can natural products serve as a viable source of lead compounds for the development of new/novel anti-malarials? Malar J. 2011 Mar 15;10(suppl 1):S2.

29. Garcia IJP, Oliveira GC, Valadares JMM, Banfi FF, Andrade SN, Freitas TR, et al. New bufadienolides extracted from Rhinella marina inhibit $\mathrm{Na}, \mathrm{K}-\mathrm{ATP}$ ase and induce apoptosis by activating caspases 3 and 9 in human breast and ovarian cancer cells. Steroids. 2019 Dec;152:108490.

30. Jaghoori MM, Bleijlevens B, Olabarriaga SD. 1001 ways to run AutoDock Vina for virtual screening. J Comput Aided Mol Des. 2016 Mar;30(3):23749.

31. Maia EHB, Medaglia LR, Silva AM, Taranto AG. Molecular architect: A user-friendly workflow for virtual screening. ACS Omega. 2020 Mar 20;5:6628-40.

32. Maia EH, Campos VA, Dos Reis Santos B, Costa MS, Lima IG, Greco SJ, et al. Octopus: a platform for the virtual high-throughput screening of a pool of compounds against a set of molecular targets. J Mol Model. 2017 Jan;23(1):26.

33. Nunes RR, Fonseca ALD, Pinto ACS, Maia EHB, Silva AMD, Varotti FP, et al. Brazilian malaria molecular targets (BraMMT): selected receptors for virtual high-throughput screening experiments. Mem Inst Oswaldo Cruz. 2019 Feb 25;114:e180465.

34. Daina A, Michielin O, Zoete V. SwissADME: a free web tool to evaluate pharmacokinetics, drug-likeness and medicinal chemistry friendliness of small molecules. Sci Rep. 2017 Mar 3;7:42717.

35. Sander T, Freyss J, Von Korff M, Rufener C. DataWarrior: an open-source program for chemistry aware data visualization and analysis. J Chem Inf Model. 2015 Feb 23;55(2):460-73.
36. Campbell CC, Collins WE, Nguen-Dinh P, Barber A, Broderson JR. Plasmodium falciparum gametocytes from culture in vitro develop to sporozoites that are infectious to primates. Science. $1982 \mathrm{Sep}$ 10;217(4564):1048-50.

37. Ranford-Cartwright LC, Hayton KL, Ferdig MT. Chapter 6 - Plasmodium Experimental Genetic Crosses. In: Malaria Parasites: Comparative Genomics, Evolution, and Molecular Biology. Carlton JM, Perkins SL, Deitsch KW editors. Horizon Scientific Press: New York. p. 127-44. 2013.

38. Bell C, Hall JE, Kyle DE, Grogl M, Ohemeng KA, Allen MA, et al. Structureactivity relationships of analogs of pentamidine against Plasmodium falciparum and Leishmania mexicana amazonensis. Antimicrob Agents Chemother. 1990 Jul;34(7):1381-6.

39. Trager $W$, Jensen JB. Human malaria parasites in continuous culture. Science. 1976 Aug 20;193(4254):673-5.

40. Lambros C, Vanderberg JP. Synchronization of Plasmodium falciparum erythrocytic stages in culture. J Parasitol. 1979 Jun;65(3):418-20.

41. Carvalho LH, Brandão MG, Santos-Filho D, Lopes JL, Krettli AU. Antimalarial activity of crude extracts from Brazilian plants studied in vivo in Plasmodium berghei-infected mice and in vitro against Plasmodium falciparum in culture. Braz J Med Biol Res. 1991;24(11):1113-23.

42. Denizot F, Lang R. Rapid colorimetric assay for cell growth and survival. Modifications to the tetrazolium dye procedure giving improved sensitivity and reliability. J Immunol Methods. 1986 May 22;89(2):271-7.

43. Twentyman PR, Fox NE, Rees JK. Chemosensitivity testing of fresh leukaemia cells using the MTT colorimetric assay. Br J Haematol. 1989 Jan;71(1):19-24.

44. Valsalam S, Agastian P, Esmail GA, Ghilan AM, Al-Dhabi NA, Arasu MV. Biosynthesis of silver and gold nanoparticles using Musa acuminata colla flower and its pharmaceutical activity against bacteria and anticancer efficacy. J Photochem Photobiol B. 2019 Dec;201:111670.

45. Karkehabadi H, Yousefifakhr H, Zadsirjan S. Cytotoxicity of endodontic irrigants on human periodontal ligament cells. Iran Endod J. 2018 Summer;13(3):390-4.

46. Costa Junior DB, Araújo JSCA, Oliveira LM, Neri FSM, Moreira POL, Taranto AG, et al. Identification of novel antiplasmodial compound by hierarquical virtual screening and assays. J Biomol Struct Dyn. 2020 May 13:1-9.

47. Neri FSM, Costa Júnior DB, Froes TQ, Silva PBG, Egito MS, Moreira $\mathrm{POL}$, et al. Antileishmanial activity evaluation of thiazolidine-2,4-dione against Leishmania infantum and Leishmania braziliensis. Parasitol Res. 2020 Jul;119(7):2263-74.

48. Pessôa MTC, Valadares JMM, Rocha SC, Silva SC, McDermott JP, Sánchez G, et al. 21-Benzylidene digoxin decreases proliferation by inhibiting the EGFR/ERK signaling pathway and induces apoptosis in HeLa cells. Steroids. 2020 Mar;155:108551.

49. do Céu de Madureira M, Paula-Martins A, Gomes M, Paiva J, Proença da Cunha A, do Rosário V. Antimalarial activity of medicinal plants used in traditional medicine in S. Tomé and Príncipe islands. J Ethnopharmacol. 2002 Jun;81(1):23-9.

50. Stoffman EJL, Clive DLJ. Synthesis of 4-haloserotonin derivatives and synthesis of the toad alkaloid dehydrobufotenine. Tetrahedron. 2010 June 19;66(25):4452-61.

51. Yoshika M, Komiyama Y, Konishi M, Akizawa T, Kobayashi T, Date M, et al. Novel digitalis-like factor, marinobufotoxin, isolated from cultured Y-1 cells, and its hypertensive effect in rats. Hypertension. 2007 Jan;49(1):209-14.

52. Torres ZES, Silveira ER, Rocha e Silva LF, Lima ES, De Vasconcellos MC, De Andrade Uchoa DE, et al. Chemical composition of Aspidosperma ulei Markgr. and antiplasmodial activity of selected indole alkaloids. Molecules. 2013 Jun;18(6):6281-97.

53. Fonseca AL, Nunes RR, Braga VML, Comar-Jr M, Alves RJ, Varotti F de $P$, et al. Docking, QM/MM, and molecular dynamics simulations of the hexose transporter from Plasmodium falciparum (PfHT). J Mol Graph Model. 2016 May;66:174-86. 
54. Kirk K, Horner HA, Kirk J. Glucose uptake in Plasmodium falciparuminfected erythrocytes is an equilibrative not an active process. Mol Biochem Parasitol. 1996 Nov 25;82(2):195-205.

55. Woodrow CJ, Burchmore RJ, Krishna S. Hexose permeation pathways in Plasmodium falciparum-infected erythrocytes. Proc Natl Acad Sci U S A. 2000 Aug 29;97(18):9931-6.

56. Cavasotto $\mathrm{CN}$. Homology models in docking and high-throughput docking. Curr Top Med Chem. 2011;11(12):1528-34.

57. Silva LR, Ferreira MMC. Estudo do coeficiente de partição octanol-água de bifenilas policloradas (PCBs) utilizando parâmetros topológicos. Quim Nova. 2003 May/Jun;26(3):312-8.

58. Gleeson MP. Generation of a set of simple, interpretable ADMET rules of thumb. J Med Chem. 2008 Feb 28;51(4):817-34.
59. Lipinski CA, Lombardo F, Dominy BW, Feeney PJ. Experimental and computational approaches to estimate solubility and permeability in drug discovery and development settings. Adv Drug Deliv Rev. 2001 Mar 1;46(1-3):3-26.

60. Mahmoudi N, Julian-Ortiz JV, Ciceron L, Gálvez J, Mazier D, Danis M. Identification of new antimalarial drugs by linear discriminant analysis and topological virtual screening. J Antimicrob Chemother. 2006 Mar;57(3):489-97.

61. Cunha-Filho GA, Resck IS, Cavalcanti BC, Pessoa CO, Moraes MO, Ferreira JRO, et al. Cytotoxic profile of natural and some modified bufadienolides from toad Rhinella schneideri parotoid gland secretion. Toxicon. 2010 Sep 1;56(3):339-48.

62. Bézivin C, Tomasi S, Lohézic-Le Dévéhat F, Boustie J. Cytotoxic activity of some lichen extracts on murine and human cancer cell lines. Phytomedicine. 2003;10(6-7):499-503. 